\title{
STUDIES ON CULTIVATION OF LEPROSY BACILLI
}

\author{
Tadao Toda and Shinya Otomo (Bact. Dep., Kyushu Univers.) \\ Yo Nakakawa and Masahiro Nakamura (Bact. Dep., Kurume. Faculty)
}

1) The addition of amino-delivates to the media seems to give a favorable effect for multiplication of bacilli.

2) We advocated as the judging method of successive culture, to describe the size and number of microscopic colonies at every generation, and to regard the increase of the size and number as positive.

3) By this judging, our culture of the leprosy bacilli were successful to second generation.

\section{獺菌の培養実驗に関する研究 特に累代培養實驗に於けろ增菌制定の一試案}

\begin{tabular}{|c|c|c|c|}
\hline 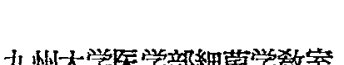 & 戶 & 田 & 忠 \\
\hline ル\% & 大 & 友 & 信 \\
\hline & 中 & 川 & \\
\hline & 中 & 村 & 昌 \\
\hline
\end{tabular}

\section{序}

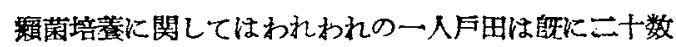
年前よりその実験を志し，さきに昭和14年その一部の成 積(1を登表し，また近くは昭和21年その後の成嘖(2)につ いて众比するところがあつた。後な打不断の努力を 続行中厄あることは論を俟たないところであるが，今回 は更にその後の成渍についていささか述へてみたいと思 万。

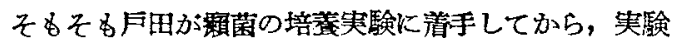

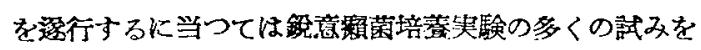
行ら一方，他面愿菌と同一のカテゴリーに属する結核菌 业に自然界抗酸菌の研究を常に本行的に行つてそれらの 性状を徹底的火究明して，その得られた成㥽から疑菌の 性状を類察乙，併せて箱菌培盖条件の示㖟を得たいと考 えたことは哴々述へたところである(3)従つて今回も結 核菌の登育促進物筫を研究中，アミノ酸注射製洞のある ものか結核菌に著しい発夻保進性を示すこと(bを䐂めた

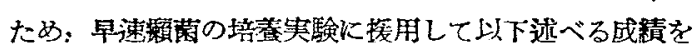
得たわけでる。な特，培篮の物理的条件閣しては中

村が占部教授の指導のるとK行つた実験方法(5一-8)をそ のまま用らることにしたのである。

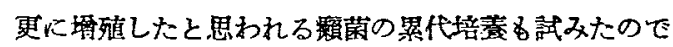
あるが，その蹬の堾殖判定浩の一つの試婪を考案したた

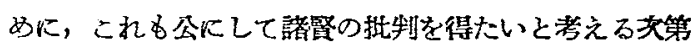
である。

\section{货詥方法並に成績}

$$
\begin{gathered}
\text { I. 人 濒 菌 } \\
\text { 笑驗方法 }
\end{gathered}
$$

车験は数回にわたつて行つているのであるけれどるて の一つ一つを逐次述べることは紙面の都合上锌されない から，次に簡単に矢験の大要を述べこととする。

共試材料：鼠䝷菌株としては久留米42号（2010）接種

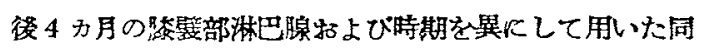

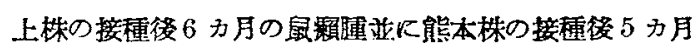

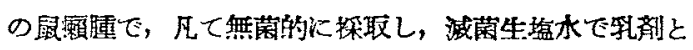

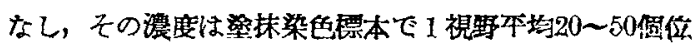


の菌数を示す程度にして，それを有針裝用の娍菌注射器 にすい上げその1滴宛を培地に移植した。

供堽琣地：

I）牛血清加 Kirchner 液に $2 \% \mathrm{CaCl}_{2}$ を狳で 3 滴添加したまの。

I）同上培地にポリタミン注射液〔武田]を10\%に添 加したもの。

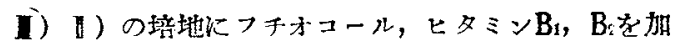
えたもの。

N) 自清加 Kirchner 没からアスパラギンを控除しそ れにポソタミン，フチオコール，ピタミン $\mathrm{B}_{1} ， \mathrm{~B}_{2}$ を加え たもの。

V) 中村培地(9)

V）血清加 Kirchner 液にアミノ酸注射製剂であるマ リアミン 1 号注射液【安原整藥加工会社〕を10\%添加し たるの。

大体以上のような培地を用いたのであつてそのPHは 凡て 6.6 として使用した。

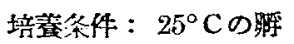
明器に收め, その外刯を 開故し分散光楾を笠入乙 ながら培鸢を行つた。

成樍判定：一定培盖日 数を歷したのち先ず肉眼 的に実験培液を雚察し头 に隇菌毛緗管ピペットて 無菌的にその沈渀を培液 の一部之共にすい上げ， それによつて梁抹標本を 作製し，Ziehl-Neelsen 染色を推したのち鏡検， 対照の加熱死菌移植の培 美管所見亚に大の管抹染 色標本と対比しながら战 鿏の判定を行つだ。

\section{苗驗成績}

成貢を一括すると第 1 表の如くである。

即ち第169より第178実験まですへてて陰性であるが，第 179，183 㕲よび184実験に打いて墂菌の徽候があつた。 とくに第184実験においては後述するような所見がえら れた。
罢代唔蓝実驗

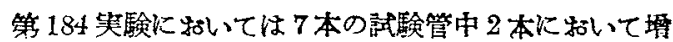

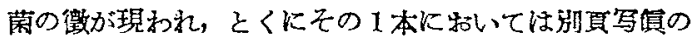
よ5に培蓋44日後に56 $\times 21 \mu$ の小集落をえたのて，これ を第2 代一累代した。

第2 代培地として注第1代と同しく牛血清加壏化カル シウム加マリアミン加 Kirchner 液を朋いた。この第 2 代は培義67日後にこれも写俱の如く2本中 1 本に拓い，て $154 \times 77 \mu$ の小集落をえた。これは明为に初代菌よりす 场大していることが制つた。头に更にこの2代小集落を 第 3 代一累代した。この晾合は境地として第 2 代培地と 同㧺の培地の外に，第 2 代培地より㙁化カルシウムを控

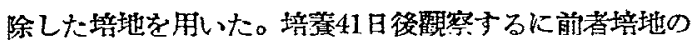
1本に $22 \times 15 \mu$ の小集落をらることが出来た。しかしこ の第 3 代集落ははるか第 2 代集落より小さいのであ つた。

以上の所見を一括すると第 2 表の如くである。
第2表（鼠頵菌累代培春実驗）

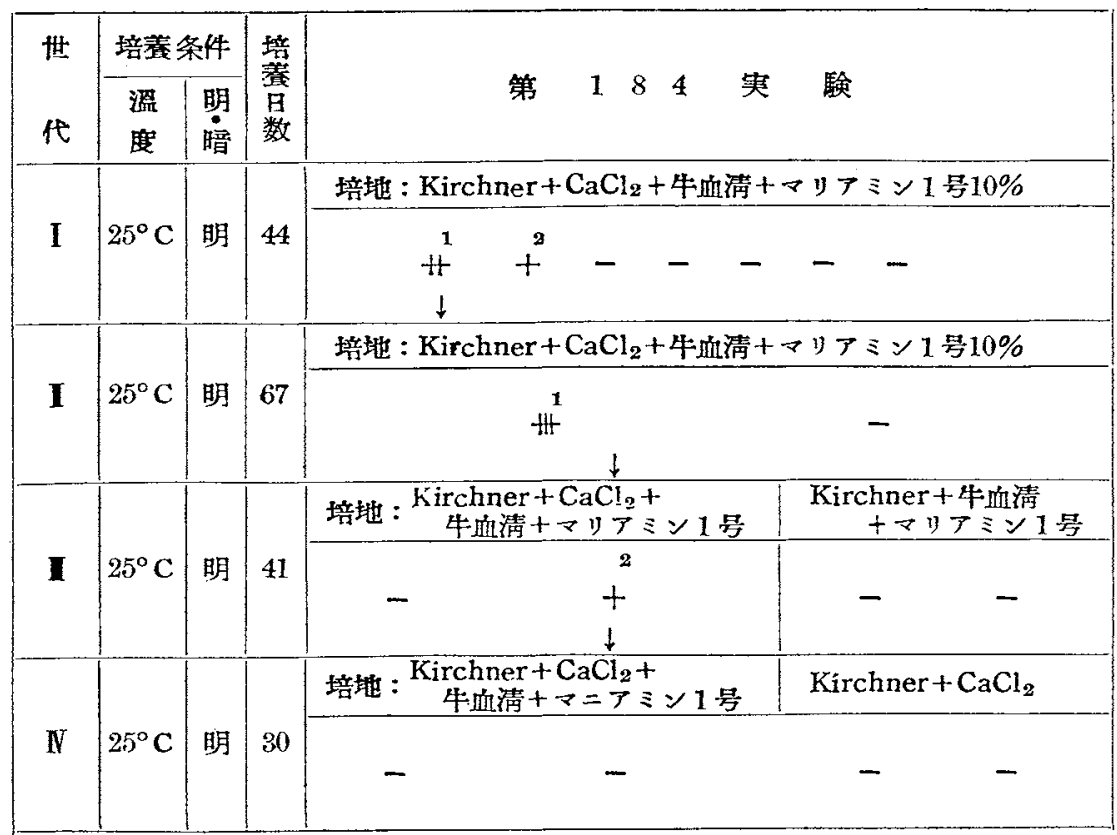

供牾材料：㐘池惠㮯園より分与をらけた第14号，第15

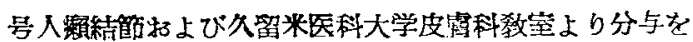

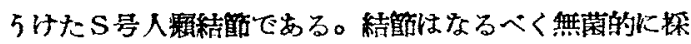


第 1 表

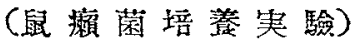

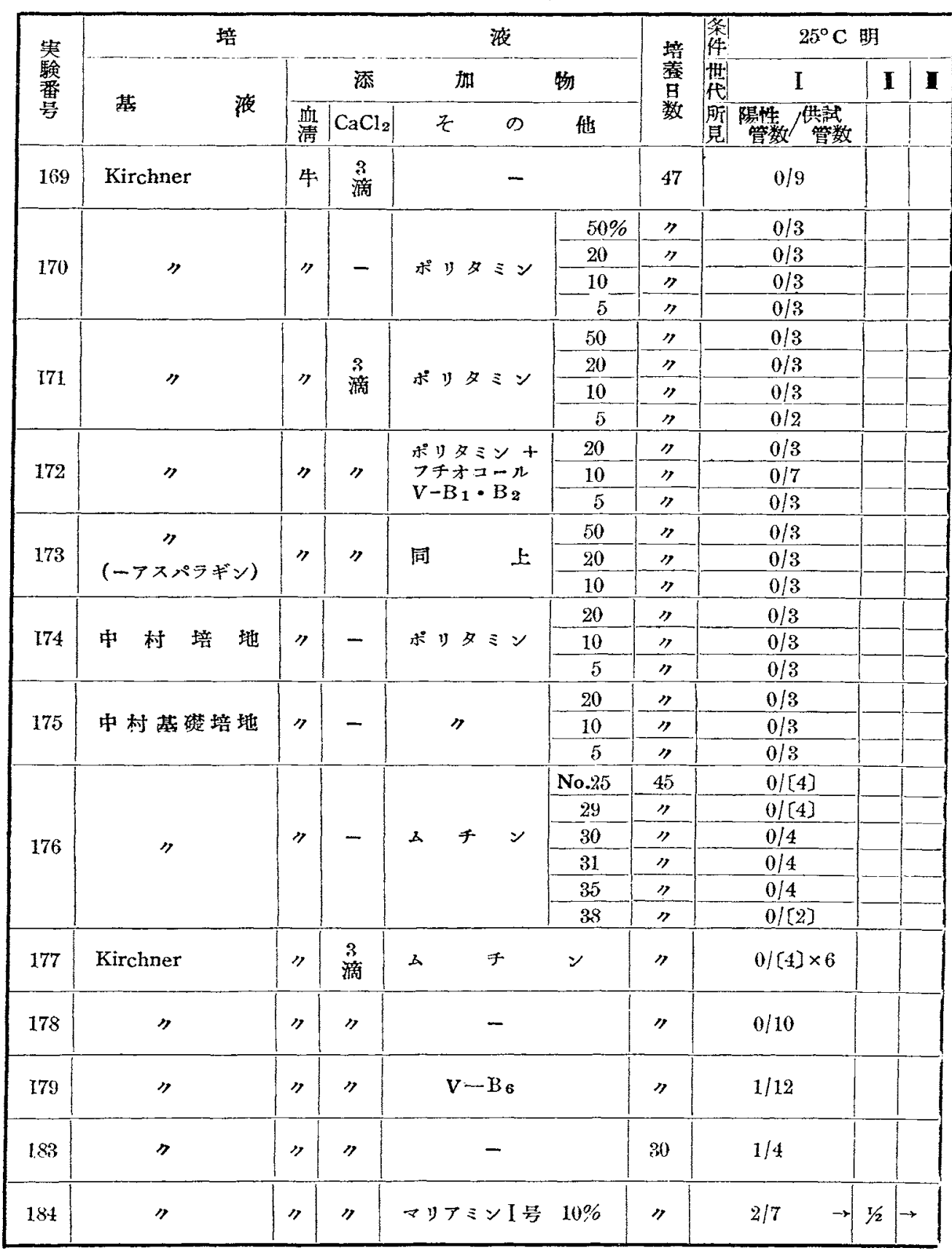

註：1）供試菌株 ： $169 \rightarrow 175$ 久留米42号， $176 \rightarrow 179$ 久留米42是 $183 \rightarrow 184$ 熊本株

2) [ ] = 雑菌 
第3表

(人瀨菌培秦実驗)

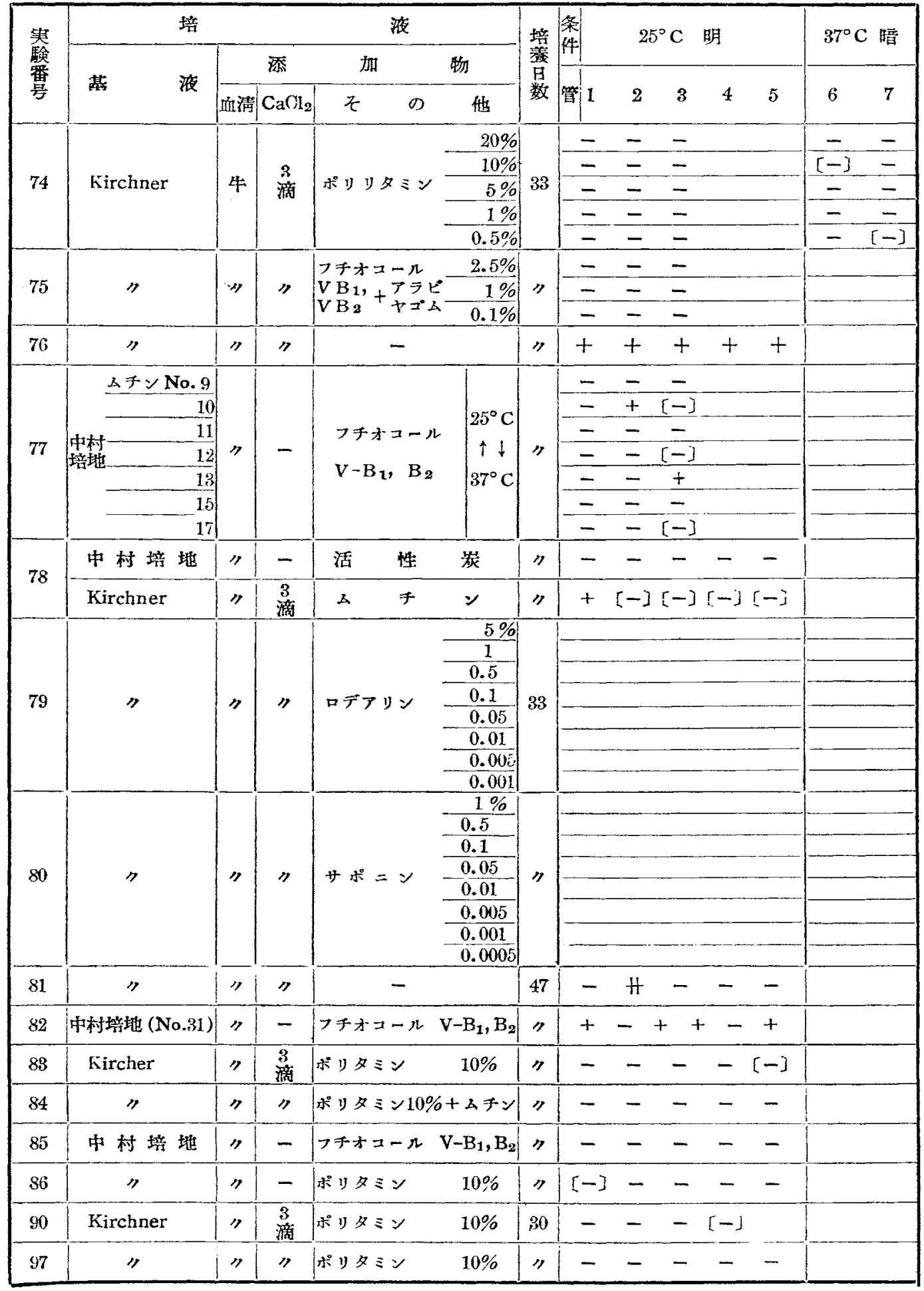

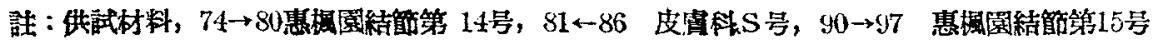


取されたが念のため $5 \% \mathrm{H}_{2} \mathrm{SO}_{4}$ で40分間処置後, 生塯

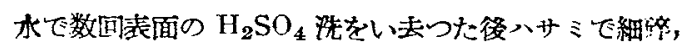

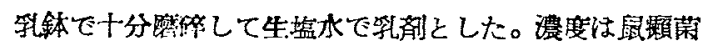

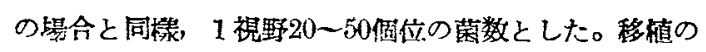

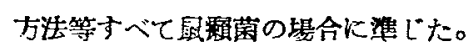

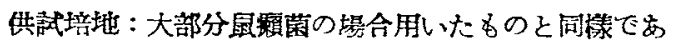
るが，第 3 䒾に一括して物く。この塂命す $\mathrm{PH}$ は6.6と した。

\section{貫 験 成 績}

第 3 表の如くである。

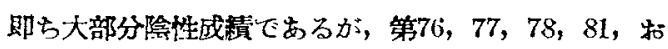
よび82実験に特いて見るべきすのがあつた。

累代培養䨋驗

1) 第 $77,81,82$ 実験

この 3 実験に乱いては初代培地と同一培地を用いて累

代培登実験を行つ たが，培盛48日後 の所見ですべて 捈く菌影をみとめ ナ成䋶は陰性とし た。

2）第76実験

この実験ては初 代菌に拁いて供試 管 5 本中 5 本に多 少の小集落か散見 されとくにその第 1 号必惊 $21 \times 14 \mu$ 大の小集落をえた ので，をれを，初 代供試培地と同一。 培地 3 本並炕飞れ に10\%の割にポリ タミンを添加した 堷地了本一累代培 等した。培蓋45日 の所見では後者の 培地中 1 本に $77 \times$ $35 \mu$ の小集落か德 本の万々に堆察さ れた。往つて第3 代炕累代した。こ

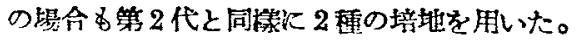
培莣79日後の所見ではその药者の培地に $98 \times 28 \mu$ の小 集落をえ，前者培地で $42 \times 22 \mu$ 小集落をえた。要に

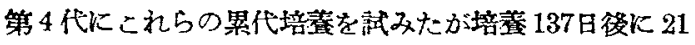
$\times 12 \mu$ の小集落劣えた。一方 $98 \times 28 \mu$ の集落消失し た。

次にこの第 4 代菌を笌 5 代に累代培盖したのに再三踶 察したが，つに菌影をみとめず渭失したるのと思われ

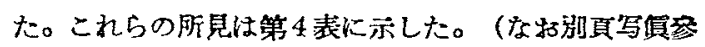
照)

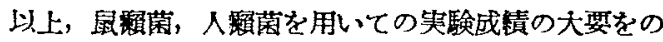
べたが，いずれの場合にも観菌の珸殖制定に際しては,

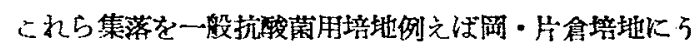
つし，これら培地上に集蕂の発生をみないことを確詪

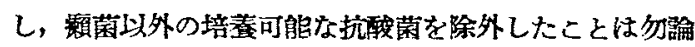
である。

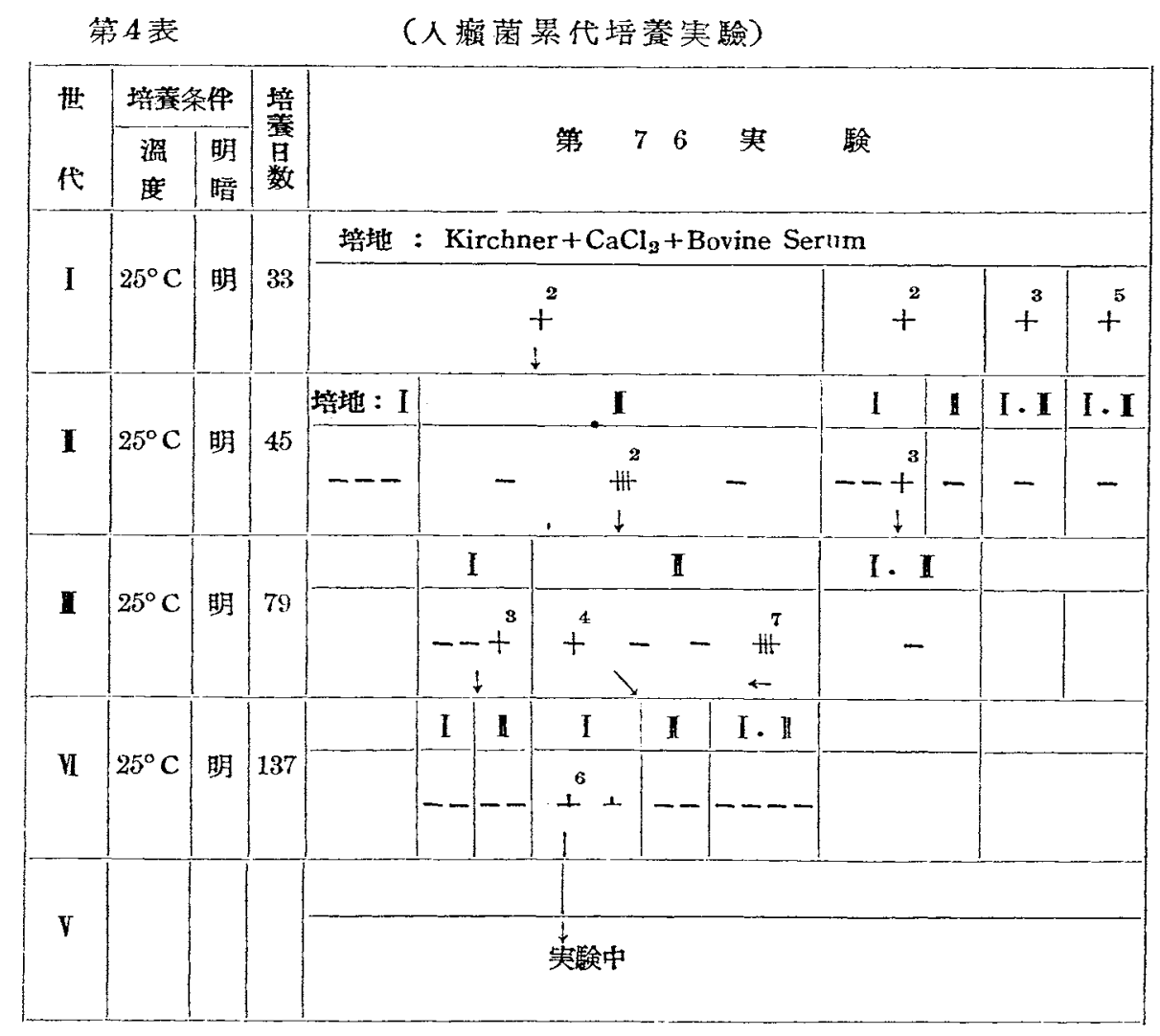

棓：培地 I, Kirchner+ $2 \% \mathrm{CaCl}^{2} 3$ 滴 培地 I，Kirchner $+2 \% \mathrm{CaCl}_{2} 3$ 滴十ポリタミン $10 \%$ 局数字，試験管番号 


\section{考察亚に總括}

上上の実験を䋓括するに先人か行つた成綪に機らかの 知見を加らることが出来之たものと偏するのであるが，

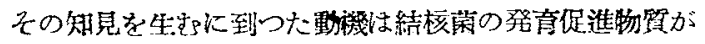

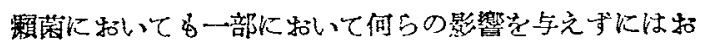
らないととを螤書きするすのの上万である。また $25^{\circ} \mathrm{C}$

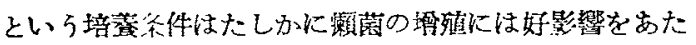

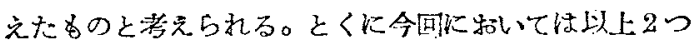
の理由のためか，圂顆菌ては 3 代，人類菌ては 4 代の累 代培䓹実験成蜍をえている。しかしながらわれわれはこ の塄合無論非難なしと法考えていいない。何となればこ

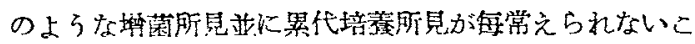
と，牤よび瀬菌の自然凝集上墦菌とを確然と区則しえな

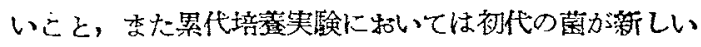

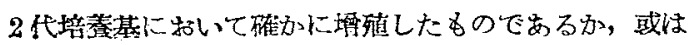
単に初代の菌を 2 代に運んだにすぎないるのであるすの かが不明であるからであること代をふるにつれて小 さくなる堨合はとくにぞの点の区別が四難である。

われわれはこの上うなととからして特に累代培蓋に牱

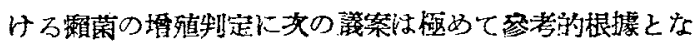

第 5 表

\begin{tabular}{|c|c|c|c|c|c|c|c|c|c|c|}
\hline \multirow{2}{*}{$\begin{array}{l}\text { 堞 } \\
\text { 代 }\end{array}$} & \multirow{2}{*}{$\begin{array}{l}\text { 培 } \\
\text { 域 } \\
\text { 数 }\end{array}$} & \multirow{2}{*}{$\begin{array}{l}\text { 管 } \\
\text { 是 }\end{array}$} & \multicolumn{3}{|r|}{ 集 } & 落 & D 長 & \multicolumn{3}{|l|}{ 经 } \\
\hline & & & $10 \sim 30 \mu$ & $31 \sim 50$ & $51 \sim 70$ & $71 \sim 90$ & $91 \sim 110$ & $111 \sim 130$ & $131 \sim 150$ & $151 \sim 170$ \\
\hline I & 4.4 & 1 & & 1 & & 1 & & & & \\
\hline $\mathbb{1}$ & 67 & 1 & & & & & & & & 1 \\
\hline I & 41 & 2 & 1 & & & & & & & \\
\hline N & 30 & & & & & & & & & \\
\hline
\end{tabular}

第 6 表

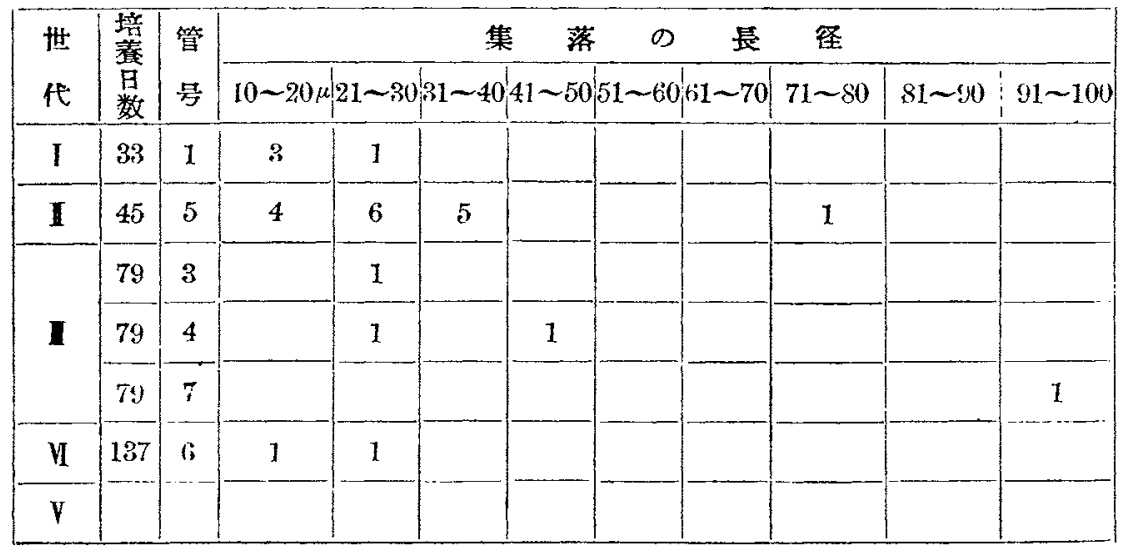

ることと信したのたここに提唱したいと考える。

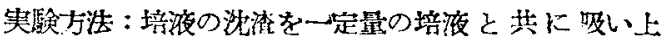

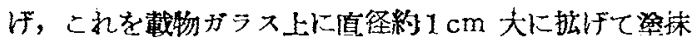

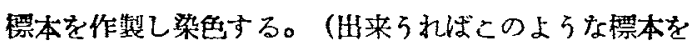
3〜5 枚作製したら更に良威瞔をらると思う。)次にこの

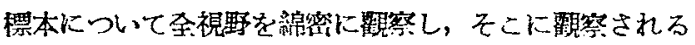
顆菌の小集落の短径 $\times$ 長堡並にその数を測定する。

2 代，3代墇液について子同㧼のことを行う。

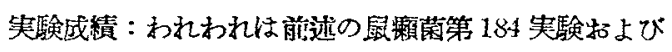

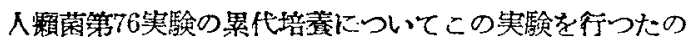
であるが成績注先ず鼠制菌で注第5表の如くである。

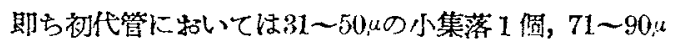

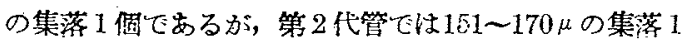

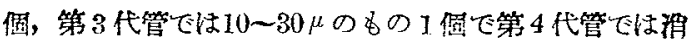
失している。

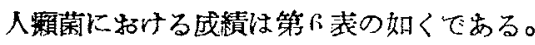

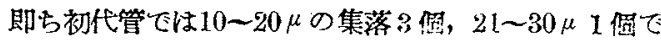

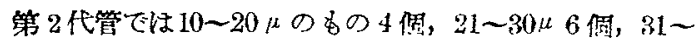

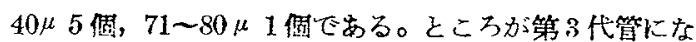

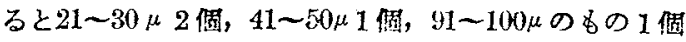
で集落の大さは1罟大な るすのを得ているが，て の数は減少している。第 4 代管になると 10 ～ $20 \mu$

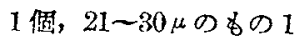
谓〔第3代管に比乙量， 貿共に著しい減少でる た。

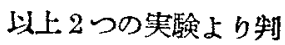
断するところによれば初 代以增殖したるのは 2 代 に及えで明かに堌殖する が，第严代上降结これを 運搬しているに過ぎない ものの如く，更に進んて 场殖しているとは考えら れなからたのである。故 にここに人㷇菌て 4 代す で培挤出来たといらには 未確信がない。

た尤れわれはここに このような1つの試みを 提唱することにより，そ の糸代培䓪矢験力成功儿 
F田・大友・中川・中村諭交

策 7 表

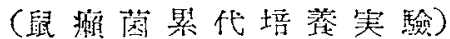

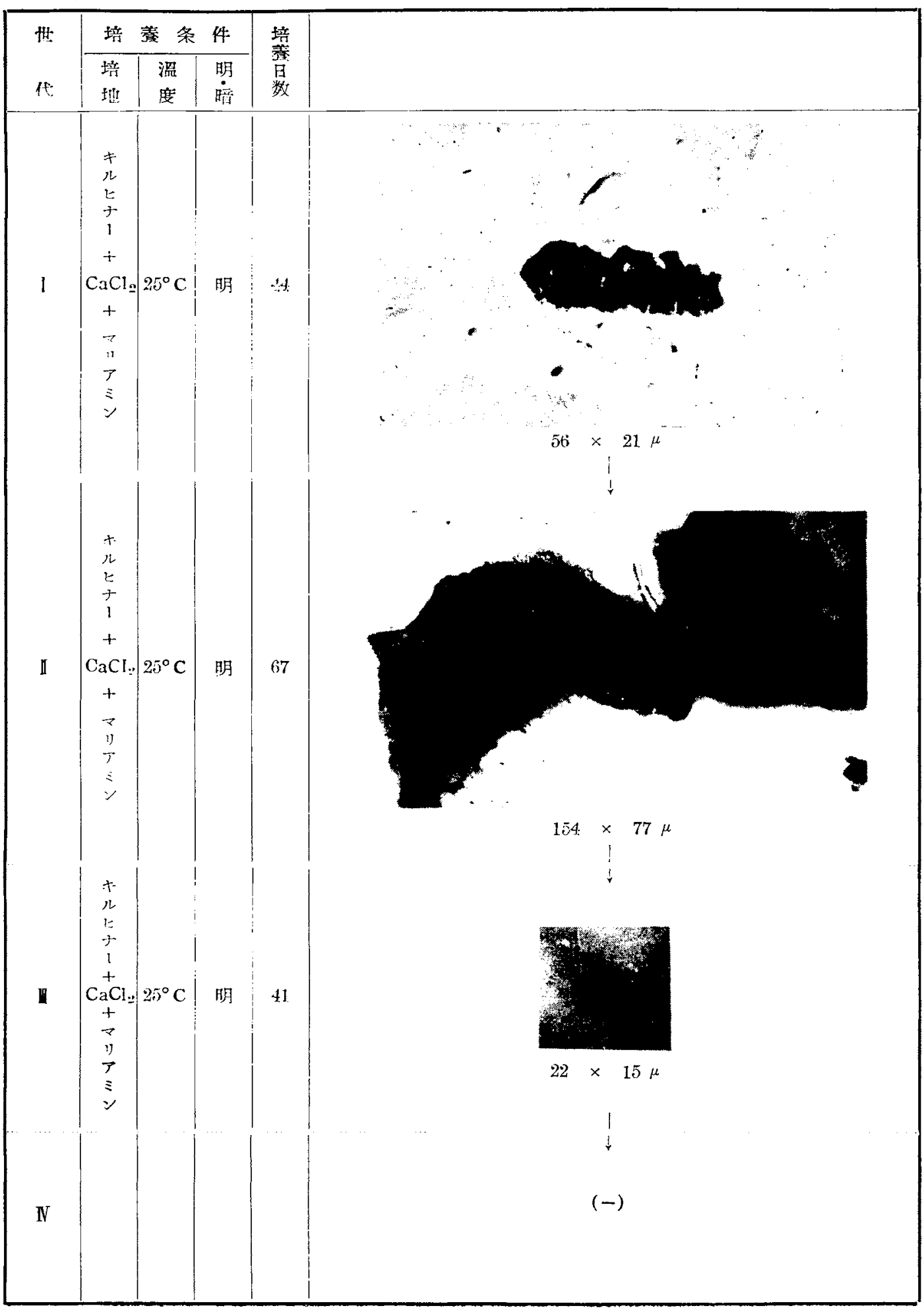


厂田・大交・师川・中村論交

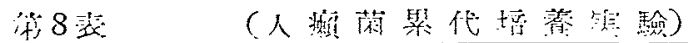

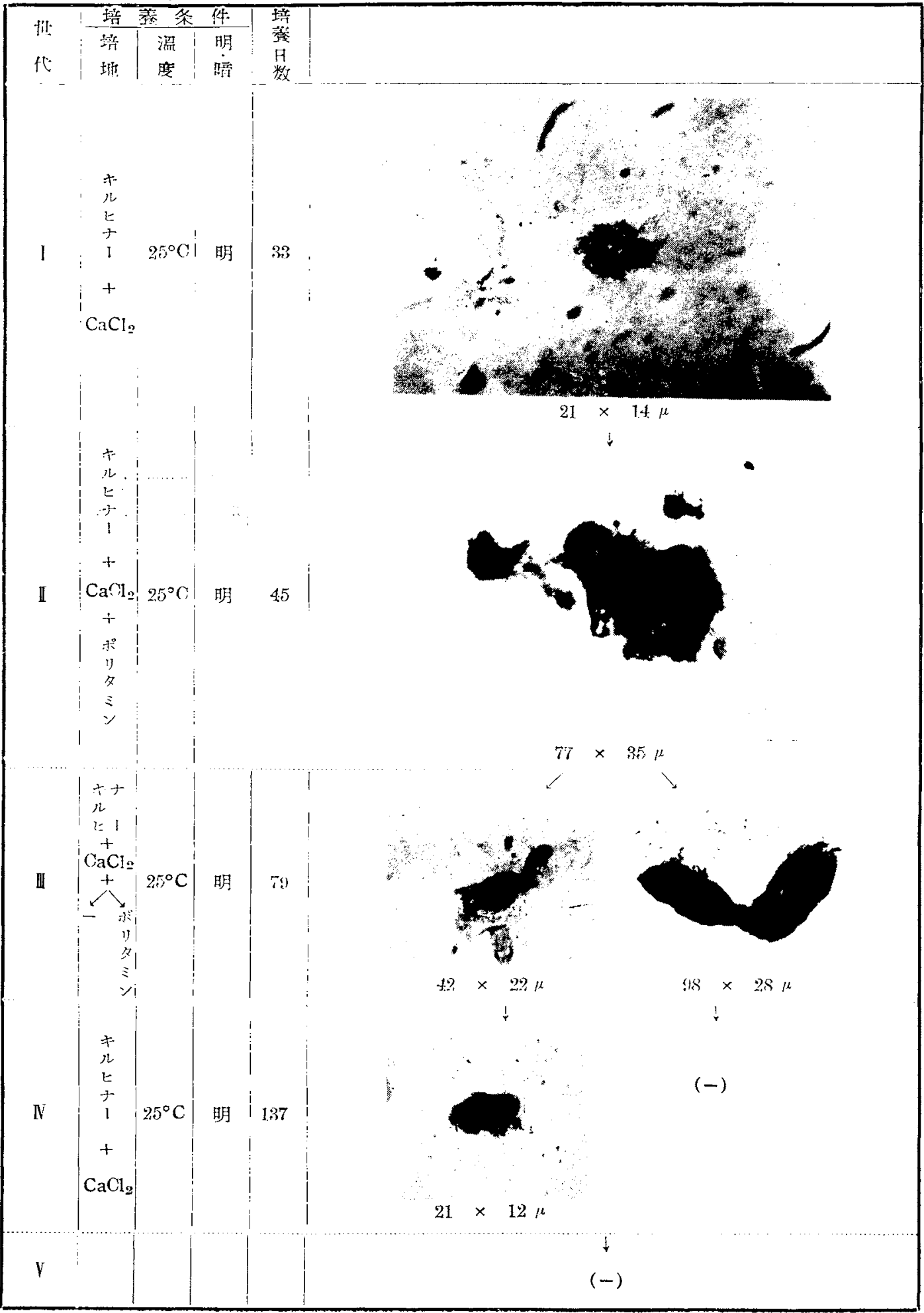


つつあるすのであるか不方を判定する車要な根據をあた

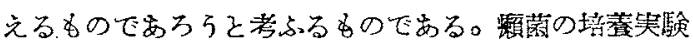

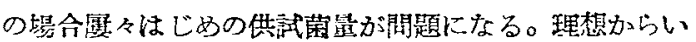
えば甚で僅少な藏監乃全単坬菌を移極してそれが著しく 诵加すれば墂殖したとするのが最す確些にして㹂明な訳

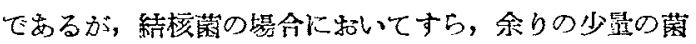

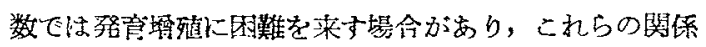

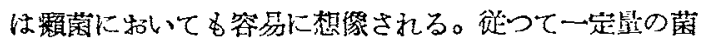
量を䔟植した方か生活力を旺盛とすると思われる，けれ ども前述の上らに謤殖制定に苦しむことが再三に止らな い。しかしながらこの場合の判定にわれわれが前䢞した

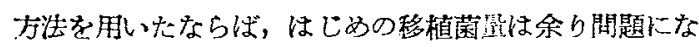

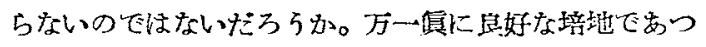
たならば菌孟の如何にかかからす常にはじめに移植され た菌より埇加せるばならないからである。

\section{結諭}

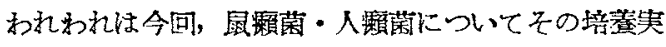
験の一部を登表した。

1）われわれの得た成續でアミノ酸注射製剂の添加

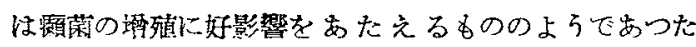
が，每常同一の成續は得られなからた。

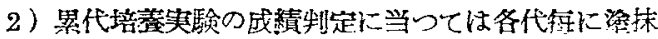
標本中に䤄察される頻菌の策落の長经 $\times$ 短经前びにその

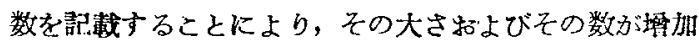

することを以て陽泩とみなす方浩を提呾した。このよろ にすれば当初の移縝菌留は余り間題にならないので注な い名と思ら。

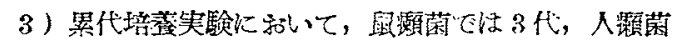
ては 4代にわたつて，それらの集落か灌察された。しか

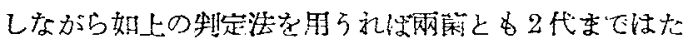

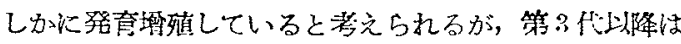

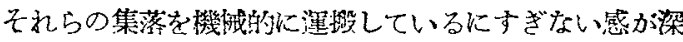
w。

(贵重なる結篦の提供をここらよく受諾下さつた获

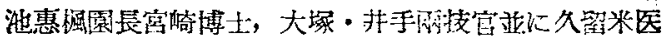
科大学重松呚授に深福与る。)

（本研觉の一部は文部省科学研究費によつた）

\section{文献}

1）下田・占部・出田：レプラ，10発，283頁，昭14年。

2）戸田・中川・山田：臨床と矿究，23管，272頁，昭2 I年。

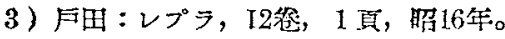

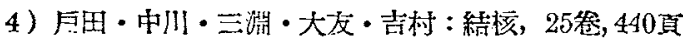
昭25年。

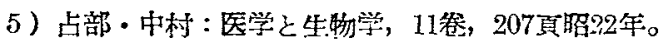

6) 占部・中村 : 医学々生物学，11赏，345頁昭22年。

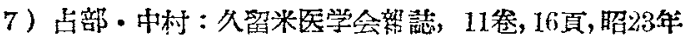

8) 中村：久留米医学会雑誌，[2恣，44頁，昭24年。

9 ）中村(敬):レプラ，18告，10頁，炤24年。 